\title{
THE ROLE OF COMMUNITY PHARMACISTS IN THE PREVENTION OF CARDIOVASCULAR DISEASES. ARE FUTURE HEALTH CARE PROVIDERS PREPARED FOR PROFESSIONAL COLLABORATION?
}

\author{
MAGDALENA JASIŃSKA-STROSCHEIN*, URSZULA KURCZEWSKA, \\ DOMINIKA WOJCIECHOWSKA, and DARIA ORSZULAK-MICHALAK
}

\author{
Department of Biopharmacy, Medical University of Lodz
}

\begin{abstract}
While community pharmacists have long played roles in the prevention and management of chronic diseases in some countries, their role in Poland has not extended beyond the traditional dispensing of medicines. However, the last months have raised expectations that the advisory role of the pharmacist will be strengthened by legislation. The present survey evaluates the opinions of different future health care providers about possible patient-centered activities that can be performed in a community pharmacy, based on the example of a patient with cardiovascular risk/disease. A self-administered questionnaire was completed by a sample of year 1 and 5 students of Laboratory Medicine, Medicine, Pharmacy and Nursing and Midwifery $(\mathrm{N}=854)$. They were asked to rank their opinions on a Likert-like scale and the underlying dimensions were identified using exploratory and confirmatory techniques. The examples of proposed activities have been included in novel polish law regulations concerning the profession of pharmacist. Five factors were identified that could classify pharmacist activities. The model displayed acceptable construct validity and internal consistency. The obtained results indicate that pharmacists have an unclear image in healthcare. The expectations of the pharmacist's role did not appear to change much over the course. Only future pharmacists considered the majority of proposed items as important activities for cardiovascular disease risk prevention in the community pharmacy. There is a need to design effective interprofessional workshops and activities to increase future health care providers' awareness of the competencies of the community pharmacists.
\end{abstract}

Keywords: cardiovascular diseases, pharmaceutical services, health promotion

Cardiovascular disease (CVD) remains the number one cause of mortality among non-communicable diseases worldwide. In 2016, 1.83 million deaths were resulting from diseases of the circulatory system in the European Union, which was equivalent to $35.7 \%$ of all deaths; this is considerably higher than the second most prevalent cause of death, cancer. In Poland, CVD accounted for 168280 deaths (43.3\%) in that year (1). CVD occurs to be influenced by many factors over time. These are modifiable risk factors, such as high blood pressure, smoking, high cholesterol, unhealthy diet, obesity, type 2 diabetes, and physical inactivity or excessive alcohol consumption, and non-modifiable factors, such as family history, ethnicity, and age. A healthy lifestyle, awareness of the disease, or adherence to medication regimen remain a major concern. In such cases, the risk and/or incidence of CVD can be reduced by modification of risk factors as well as health education and optimization of pharmacotherapy. Undoubtedly, a community pharmacist can make a positive contribution in this process by improving the cardiovascular care of patients through interventions related to screening for the presence of risk factors, risk behavior counseling, and education, such as smoking cessation, monitoring of pharmacotherapy, and adherence (2).

In the US and some European countries, community pharmacists have long undertaken roles in both primary and secondary prevention and management of chronic diseases, such as CVD, that extend beyond the traditional dispensing of medicines. The concept of pharmaceutical care being defined as the responsible provision of pharmacotherapy for the purpose of achieving definite outcomes that improve a patient's quality of life (3) was incorporated into Polish legislation in 2008. However such activities as patient's referral or medication history taking were lacking before new regulations came into force in 2021, and this is not on par with the evolving role of community pharmacists in other parts of the world

* Corresponding author: e-mail: magdalena.jasinska-stroschein@umed.lodz.pl 
Table 1 . The overview of the competencies of community pharmacists in example countries*.

\begin{tabular}{|c|c|c|c|c|c|c|}
\hline Item & Poland\# & US & Canada & Portugal & France & Great Britain \\
\hline Vaccination & No & $\begin{array}{l}\text { Yes, but } \\
\text { there can be } \\
\text { differences } \\
\text { among states }\end{array}$ & $\begin{array}{c}\text { Yes - influenza } \\
\text { in most } \\
\text { provinces }\end{array}$ & $\begin{array}{l}\text { Yes - } \\
\text { vaccinations not } \\
\text { included in the } \\
\text { immunization } \\
\text { schedule }\end{array}$ & Yes - influenza & Yes - influenza \\
\hline $\begin{array}{c}\text { Identification and } \\
\text { evaluation of DRPs }\end{array}$ & No & Yes & Yes & Yes & Yes & Yes \\
\hline BP measurements & No & Yes & Yes & Yes & Yes & Yes \\
\hline $\begin{array}{l}\text { Blood glucose } \\
\text { measurements }\end{array}$ & No & Yes & $\begin{array}{l}\text { Yes, in some } \\
\text { provinces }\end{array}$ & Yes & Yes & $\begin{array}{c}\text { Depending on } \\
\text { local regulations }\end{array}$ \\
\hline $\begin{array}{c}\text { Blood lipid } \\
\text { measurements }\end{array}$ & No & Yes & No & Yes & No & No \\
\hline BMI monitoring & No & No data & $\begin{array}{l}\text { Yes, in some } \\
\text { provinces }\end{array}$ & Yes & Yes & Yes \\
\hline Smoking cessation & No & Yes & Yes & Yes & Yes & Yes \\
\hline $\begin{array}{c}\text { Access to } \\
\text { patient medical } \\
\text { documentation }\end{array}$ & No & $\begin{array}{l}\text { Yes, concerns } \\
\text { some parts of } \\
\text { documentation }\end{array}$ & $\begin{array}{l}\text { Yes, in some } \\
\text { provinces }\end{array}$ & $\begin{array}{l}\text { Yes, concerns } \\
\text { some parts of } \\
\text { documentation }\end{array}$ & $\begin{array}{c}\text { Yes, concerns } \\
\text { some parts of } \\
\text { documentation }\end{array}$ & $\begin{array}{l}\text { Yes, concerns } \\
\text { some parts of } \\
\text { documentation }\end{array}$ \\
\hline $\begin{array}{l}\text { Prescription of } \mathrm{Rx} \\
\text { drug }\end{array}$ & $\begin{array}{c}\text { Yes, in } \\
\text { case of } \\
\text { patient's } \\
\text { health and } \\
\text { life risk }\end{array}$ & $\begin{array}{l}\text { Yes, but } \\
\text { there can be } \\
\text { differences } \\
\text { among states }\end{array}$ & $\begin{array}{c}\text { Yes, but } \\
\text { there can be } \\
\text { differences } \\
\text { among } \\
\text { provinces }\end{array}$ & No data & $\begin{array}{l}\text { Yes, in case } \\
\text { of drug } \\
\text { prolongation }\end{array}$ & $\begin{array}{l}\text { Yes, concerns } \\
\text { prescribing } \\
\text { permissions of } \\
\text { independent } \\
\text { prescriber }\end{array}$ \\
\hline Generic substitution & Yes & $\begin{array}{l}\text { Yes, in some } \\
\text { states }\end{array}$ & $\begin{array}{c}\text { Yes, the } \\
\text { medicines are } \\
\text { prescribed } \\
\text { according to } \\
\text { INN system** }\end{array}$ & $\begin{array}{c}\text { Yes, the } \\
\text { medicines are } \\
\text { prescribed } \\
\text { according to } \\
\text { INN system** }\end{array}$ & No & $\begin{array}{l}\text { Yes, in some } \\
\text { districts }\end{array}$ \\
\hline $\begin{array}{l}\text { New medicine } \\
\text { service }\end{array}$ & No & Yes & No & No & No & Yes \\
\hline
\end{tabular}

*The following table presents only a few examples of countries where community pharmacists' roles were extended,

** INN=International Nonproprietary Names, \# before the entry into force of the act on the profession of pharmacist

(Dz.U. 2021. 97). Based on (5-10).

(Table 1). The activities which are core elements of pharmaceutical care provision, e.g. identification of drug-related problems within medication reviews and documentation of interventions, have been for months under public debate; it has borne fruit in novel law on the profession of the pharmacist (4).

On the other hand, the recent months of the COVID-19 pandemic crisis have brought new challenges for community pharmacists; besides their classic role as a source of medication. These have included maintaining infection control in the pharmacy and facilitating patient education regarding COVID-19 prevention products and medical equipment supplies. Polish pharmacists have been also at the frontline and remained open. They have become the first point of contact while access and availability to general practitioners were difficult. In that time community pharmacists have been permitted to prescribe Rx medications for the purposes of continued treatment - if the receipt was for the pharmacist or his family. It is expected now that there will be more regulations that will strengthen the pharmacist competencies, and the patient-centered approach could finally become common practice rather than just a professional aspiration.

Therefore, the present study examines the attitudes of future health-related professionals to the contribution of community pharmacists regarding health promotion and optimization of patient pharmacotherapy. Although previous papers have examined the issues of pharmaceutical care in general (11-12), the current study focuses on a specific group of patients with unsatisfactory morbidity and mortality rates in Poland i.e. those with CVD diseases / or risk factors.

A survey was administered to the students of the Medical University of Lodz (Poland). The survey examined the attitudes of first-year and fifthyear Laboratory Medicine, Medicine, Pharmacy, and Nursing and Midwifery students toward the contribution of community pharmacists in the prevention of cardiovascular risk and diseases. 
The first aim was to determine the construct validity and internal consistency of the self-administered questionnaire based on this proposed set of categories. In addition, to evaluate the preparedness for future collaboration with community pharmacists, the study examines the perception of community pharmacist activities by students, reviews the factor structure of the questionnaire, identifies trends visible between $1^{\text {st }}$ and $5^{\text {th }}$-year students, and compares these with the basic knowledge of CVD risk factors among students. The findings will then be used to develop a more universally applicable tool to assess opinions about the particular activities of community pharmacists.

\section{EXPERIMENTAL}

Study design. This was an observational study carried out with students of the Faculty of Pharmacy at the Medical University of Lodz (Poland).

Data collection. The study sample included a group of first and fifth-year students of the following faculties: Laboratory Medicine, Medicine, Nursing and Midwifery, Pharmacy. The questionnaires were distributed in the classrooms (November 2019 - February 2020). After the researchers explained the study and guaranteed confidentiality and anonymity, the participants were asked to complete it. The researchers informed the students that their participation was voluntary and anonymous. The average time for completion was $30 \mathrm{~min}$. Students were not allowed to look up answers during the survey. The participants were prevented from using mobile devices during the survey.

Instruments. The self-reporting questionnaire was provided in Polish, and was translated into English, and contained three sections. The first section consisted of six single-choice questions concerning socio-demographic variables: nationality, age, sex, place of residence, future career choices. The second section was a specific knowledge test that included fifteen multiple-choice questions about risk factors that increase the probability of CVD. The questions were chosen randomly. A three-member panel was appointed of experts from the area of pharmacotherapy and pharmaceutical care. They had relevant experience within education. The panel proposed a list of 30 common questions according to a review of present teaching standards for Laboratory Medicine, Medicine, Nursing and Midwifery, and Pharmacy, as well as existing European and national recommendations for the prevention of cardiovascular diseases. Any disagreements within the selection or interpretation of questions were resolved through verbal discussion with an independent researcher (M.J-S. or U.K). The third section was based on a 5-point Likert-like scale and included 24 statements about respondent attitudes toward the contribution of community pharmacists in the prevention of cardiovascular disease, according to current polish legislation and based on professional experience in other countries. The Likert Scale was proposed as it does not require the participant to provide a simple and concrete "yes or no" answer and does not force the participant to take a stand on a particular topic. The possible responses were arranged on a five-point scale ranging from "strongly disagree" (1 point) to "strongly agree" (5 points). The instrument was pretested on a sample of 20 students who were randomly selected from the target population in order to test the questions and decrease the risk of any misunderstanding or misinterpretation. The students who completed the pre-test were not included in the subsequent analysis.

Data analysis. The results were analyzed with STATISTICA 13 software. The responses addressed to section 3 were ranged from 'strongly disagree' 1 point to 'strongly agree' - 5 points and were analyzed using principal component analysis (PCA). A randomly selected sample of 248 cases (approximately one-third of all) was subjected to validation of the 5-point Likert scale. Equamax rotation was used to determine the scale factors. The Likert-like scale was modified by assessing the loadings and removing any unnecessary or redundant items. Cronbach's alpha was calculated to determine the scale's reliability according to each factor, separately. The KaiserMeyer-Olkin (KMO) measure of sampling adequacy and Bartlett's test of sphericity were used to verify the hypothesis that the correlation matrix is an identify matrix. Confirmatory item analysis (CIA) was then used to evaluate the goodness of fit of the statistical model to the modified Likert-like scale by calculating the Root Mean Square Error of Approximation (RMSEA) and Goodness of Fit Indices (GFI). The chi-square test was used to test the statistical significance of differences among subgroups of participants (faculty or year of the study) with regard to the frequency distribution of categorical demographic variables (section 1). The non-parametric Mann Whitney U-test or Kruskal-Wallis test was used to compare the mean ranks from section 2, where the questions were coded as 1 (right answer) or 0 (wrong answer), and section 3 (one to five point Likert scale) in onefactor analysis. Finally, the principal component analysis (PCA) was used to calculate factor scores. The Kruskal-Wallis test was used to compare the subgroups (faculty or study year), according to obtained 
factor scores. The correlations between the overall score in the knowledge test - calculated as the ratio of the number of correct answers to all - and factor loadings were assessed using the non-parametric Spearman test.

A p-value of less than 0.05 was considered statistically significant.

\section{RESULTS}

\section{Demographic profile of respondents}

A total of 1907 students took the survey and 854 responded (a 45\% response rate). More than 90 percent of responses were obtained from Pharmacy (94.6\%) and Laboratory Medicine (100\%) faculties. The questionnaires were completed by $54.6 \%$ of future nurses and by $31.8 \%$ of Medicine students, adequately. Such differences at least partially result from disproportions in the number of students of particular faculties at the Medical University of Lodz; e.g. there were more than 1300 of $1^{\text {st }}$ and $5^{\text {th }}$ year Medicine students, and only sixty future diagnosticians (both $1^{\text {st }}$ and $5^{\text {th }}$-year study) in the year of completing the survey. The majority of applicants who responded were female, both for the year 1 and 5 as well as for four faculties; the lowest percentage (64-65\%) was observed in the Faculty of Medicine. No significant relationship was found between gender ratio and study year (Table 2). Regarding the preferred place of future employment, significant variation was found with regard to faculty and study year $\left(\mathrm{P}<0.0001\right.$; chi-square test). The $5^{\text {th }}$ year students were more decided according to their professional plans, e.g. the majority of medical students or

Table 2. Characteristics of respondents according to the faculty and year of study $(\mathrm{N}=854)$.

\begin{tabular}{|c|c|c|c|}
\hline \multicolumn{4}{|c|}{ Demographic characteristics } \\
\hline Faculty & \multicolumn{3}{|c|}{ Laboratory medicine } \\
\hline Study year & $1^{\text {st }}$ & $5^{\text {th }}$ & Total \\
\hline Number of participants (\%) & $41(66.1)$ & $21(33.9)$ & $62(100)$ \\
\hline Age (median) & $19(19)$ & $23(23)$ & $19(19,23)$ \\
\hline Female $(\%)$ & $36(87.5)$ & $18(85.7)$ & $54(87.1)$ \\
\hline $\begin{array}{c}\text { Nationality (\%) } \\
\text { Polish } \\
\text { Place of origin }(\%) \\
\text { Village } \\
\text { City of }<50000 \text { inhabitants } \\
\text { City of } 50000 \text { to } 500000 \text { inhabitants } \\
\text { City of }>500000 \text { inhabitants }\end{array}$ & $\begin{array}{c}41(100) \\
13(31.7) \\
9(21.9) \\
7(17.1) \\
12(29.3)\end{array}$ & $\begin{array}{l}21(100) \\
8(38.1) \\
7(33.3) \\
3(14.3) \\
3(14.3)\end{array}$ & $\begin{array}{l}62(100) \\
21(33.9) \\
16(25.8) \\
10(16.1) \\
15(24.2)\end{array}$ \\
\hline Faculty & \multicolumn{3}{|c|}{ Medicine } \\
\hline Number of participants (\%) & $264(62.6)$ & $160(37.7)$ & $424(100)$ \\
\hline Age (median) & $20(19,20)$ & $24(23,25)$ & $21(19,23)$ \\
\hline Female $(\%)$ a & $169(64.0)$ & $102(63.7)$ & $272(64.1)$ \\
\hline $\begin{array}{c}\text { Nationality (\%) } \\
\text { Polish } \\
\text { Place of origin }(\%) \\
\text { Village } \\
\text { City of }<50000 \text { inhabitants } \\
\text { City of } 50000 \text { to } 500000 \text { inhabitants } \\
\text { City of }>500000 \text { inhabitants }\end{array}$ & $\begin{array}{c}222(84.1) \\
54(20.4) \\
41(15.5) \\
68(25.7) \\
101(38.3)\end{array}$ & $\begin{array}{l}153(95.6) \\
25(15.6) \\
25(15.6) \\
30(18.7) \\
80(50.0)\end{array}$ & $\begin{array}{c}375(88.4) \\
79(18.6) \\
66(15.5) \\
98(23.1) \\
181(42.7)\end{array}$ \\
\hline Faculty & \multicolumn{3}{|c|}{ Pharmacy } \\
\hline Number of participants (\%) & $154(70.0)$ & $66(30.0)$ & $220(100)$ \\
\hline Age (median; min, max) & $19(19)$ & $23(24)$ & $19(19,23)$ \\
\hline Female $(\%)$ a & $113(73.4)$ & $65(98.5)$ & $178(80.9)$ \\
\hline $\begin{array}{c}\text { Nationality } \\
\text { Polish } \\
\text { Place of origin }(\%) \\
\text { Village } \\
\text { City of }<50000 \text { inhabitants } \\
\text { City of } 50000 \text { to } 500000 \text { inhabitants } \\
\text { City of }>500000 \text { inhabitants }\end{array}$ & $\begin{array}{l}152(98.7) \\
65(42.2) \\
27(17.5) \\
30(19.5) \\
32(20.8)\end{array}$ & $\begin{array}{c}65(98.5) \\
16(24.2) \\
9(13.6) \\
10(15.2) \\
31(47.0)\end{array}$ & $\begin{array}{l}217(98.6) \\
81(36.8) \\
36(16.4) \\
40(18.2) \\
63(28.6)\end{array}$ \\
\hline
\end{tabular}


Table 2. Characteristics of respondents according to the faculty and year of study $(\mathrm{N}=854)$; cont.

\begin{tabular}{|c|c|c|c|}
\hline \multicolumn{4}{|c|}{ Demographic characteristics } \\
\hline Faculty & \multicolumn{3}{|c|}{ Nursing and Midwifery } \\
\hline Number of participants (\%) & $99(66.9)$ & $49(34.1)$ & $148(100)$ \\
\hline Age (median) & $19(19,20)$ & $24(23,25)$ & $20(19,23)$ \\
\hline Female $(\%)$ a & $92(92.9)$ & $47(95.9)$ & $139(93.9)$ \\
\hline $\begin{array}{c}\text { Nationality (\%) } \\
\text { Polish } \\
\text { Place of origin }(\%) \\
\text { Village } \\
\text { City of }<50000 \text { inhabitants } \\
\text { City of } 50000 \text { to } 500000 \text { inhabitants } \\
\text { City of }>500000 \text { inhabitants }\end{array}$ & $\begin{array}{l}98(98.9) \\
58(58.6) \\
16(16.2) \\
11(11.1) \\
14(14.2) \\
\end{array}$ & $\begin{array}{c}49(100) \\
10(20.4) \\
2(4.8) \\
9(18.4) \\
28(57.2) \\
\end{array}$ & $\begin{array}{c}147(99.3) \\
68(45.9) \\
18(12.2) \\
20(13.5) \\
42(28.4) \\
\end{array}$ \\
\hline \multicolumn{4}{|c|}{ Professional Plans } \\
\hline Faculty $^{\mathrm{a}, \mathrm{b}}$ & \multicolumn{3}{|c|}{ Laboratory Medicine } \\
\hline $\begin{array}{c}\text { Hospital } \\
\text { Community pharmacy } \\
\text { Hospital pharmacy } \\
\text { University } \\
\text { Pharmaceutical Industry } \\
\text { Diagnostic Laboratory Service } \\
\text { Community Health Centre } \\
\text { Sanitary-epidemiological station } \\
\text { Blood Donation Centre } \\
\text { I do not know }\end{array}$ & $\begin{array}{c}9(21.9) \\
- \\
- \\
9(21.9) \\
2(4.9) \\
10(24.4) \\
- \\
1(2.4) \\
5(12.2) \\
5(12.2)\end{array}$ & $\begin{array}{c}2(9.5) \\
- \\
- \\
3(14.3) \\
- \\
8(38.1) \\
- \\
- \\
4(19.0) \\
4(19.0)\end{array}$ & $\begin{array}{c}11(17.7) \\
- \\
- \\
12(19.3) \\
2(3.2) \\
18(29.0) \\
- \\
1(1.6) \\
9(14.5) \\
9(14.5)\end{array}$ \\
\hline Faculty ${ }^{\mathrm{a}, \mathrm{b}}$ & \multicolumn{3}{|c|}{ Medicine } \\
\hline $\begin{array}{c}\text { Hospital } \\
\text { Community pharmacy } \\
\text { Hospital pharmacy } \\
\text { University } \\
\text { Pharmaceutical Industry } \\
\text { Diagnostic Laboratory Service } \\
\text { Sanitary-epidemiological station } \\
\text { Community Health Centre } \\
\text { Blood Donation Centre } \\
\text { I do not know }\end{array}$ & $\begin{array}{c}175(66.3) \\
1(0.4) \\
- \\
11(4.2) \\
2(0.7) \\
1(0.4) \\
- \\
50(18.9) \\
1(0.4) \\
23(8.7) \\
\end{array}$ & $\begin{array}{c}126(78.7) \\
- \\
- \\
2(1.2) \\
- \\
- \\
- \\
25(15.6) \\
- \\
7(4.4)\end{array}$ & $\begin{array}{c}301(71.0) \\
1(0.2) \\
- \\
13(3.1) \\
2(0.5) \\
1(0.2) \\
- \\
75(17.7) \\
1(0.2) \\
30(7.1) \\
\end{array}$ \\
\hline Faculty ${ }^{\mathrm{a}, \mathrm{b}}$ & \multicolumn{3}{|c|}{ Pharmacy } \\
\hline $\begin{array}{c}\text { Hospital } \\
\text { Community pharmacy } \\
\text { Hospital pharmacy } \\
\text { University } \\
\text { Pharmaceutical Industry } \\
\text { Diagnostic Laboratory Service } \\
\text { Sanitary-epidemiological station } \\
\text { Community Health Centre } \\
\text { Blood Donation Centre } \\
\text { I do not know }\end{array}$ & $\begin{aligned} & 6(3.9) \\
& 31(20.1) \\
& 8(5.2) \\
& 21(13.6) \\
& 72(46.7) \\
& 3(1.9) \\
&- \\
& 3(1.9) \\
&- \\
& 10(6.5) \\
&\end{aligned}$ & $\begin{array}{c}1(1.5) \\
38(57.6) \\
6(9.1) \\
2(3.0) \\
11(16.7) \\
- \\
- \\
- \\
- \\
8(12.1) \\
\end{array}$ & $\begin{array}{c}7(3.2) \\
69(31.4) \\
14(6.4) \\
23(10.4) \\
83(37.8) \\
3(1.3) \\
- \\
3(1.3) \\
- \\
18(8.2) \\
\end{array}$ \\
\hline Faculty ${ }^{\mathrm{a}, \mathrm{b}}$ & \multicolumn{3}{|c|}{ Nursing and Midwifery } \\
\hline $\begin{array}{c}\text { Hospital } \\
\text { Community pharmacy } \\
\text { Hospital pharmacy } \\
\text { University } \\
\text { Pharmaceutical Industry } \\
\text { Diagnostic Laboratory Service } \\
\text { Sanitary-epidemiological station } \\
\text { Community Health Centre } \\
\text { Blood Donation Centre } \\
\text { I do not know }\end{array}$ & $\begin{array}{c}75(75.7) \\
- \\
- \\
1(1.0) \\
- \\
3(1.9) \\
- \\
15(15.1) \\
2(2.0) \\
6(6.0)\end{array}$ & $\begin{array}{c}47(96.0) \\
- \\
- \\
- \\
- \\
- \\
- \\
1(2.0) \\
- \\
1(2.0)\end{array}$ & $\begin{array}{c}122(82.4) \\
- \\
- \\
1(0.7) \\
- \\
3(1.3) \\
- \\
16(10.8) \\
2(1.3) \\
7(4.7)\end{array}$ \\
\hline
\end{tabular}

${ }^{\text {aP }}<0.0001$ Chi-Square Test - First variable: Faculty and second variable: Preferred place of future employment; ${ }^{\text {b }} \mathrm{P}<0.0001$ Chi-Square Test - First variable: Year of the study and second variable: Preferred place of future employment 
Table 3. Questions ranked by mean percentage of corrected responses given by all students.

\begin{tabular}{|c|c|c|}
\hline No & Question & $\begin{array}{l}\text { Correct answers } \\
\mathrm{N}(\%)\end{array}$ \\
\hline 8 & $\begin{array}{c}\text { Prevention of CVD involves improving risk factors through lifestyle interventions such as } \\
\text { smoking cessation. The right answer is: } \square \text { Smoking can be associated with higher BP levels } \\
\text { or resting heart rate; } \square \text { Deleterious effects of passive smoking have not been confirmed, } \\
\text { yet; } \square \text { Electronic cigarettes (e-cigarettes) are recommended tool for smoking cessation; } \\
\square \text { Combining behavioral support with pharmacotherapy does not increase the success rate of } \\
\text { smoking cessation }\end{array}$ & $782(92.3)$ \\
\hline 1 & $\begin{array}{c}\text { Prevention of cardiovascular disease can involve: } \square \text { Improving lifestyle in healthy people; } \\
\square \text { Reducing risk factors in patients with established disease, eg. by optimization of } \\
\text { pharmacotherapy; Screening tests; } \square \text { All of the above }\end{array}$ & $653(77.1)$ \\
\hline 10 & $\begin{array}{c}\text { Common causes of secondary hypertension are: } \square \text { Obstructive sleep apnea; } \square \text { Endocrine } \\
\text { causes; } \square \text { Renovascular disease; } \square \text { All of the above }\end{array}$ & $594(70.1)$ \\
\hline 5 & $\begin{array}{l}\text { Low dose acetylsalicylic acid (aspirin) is: } \square \text { Recommended for all hypertensive patients; } \\
\square \text { Recommended for secondary prevention of cardiovascular diseases; } \square \text { Recommended for } \\
\text { all patients with diabetes mellitus (DM); } \square \text { Not associated with major bleeding risk when it } \\
\text { is administered chronically }\end{array}$ & $577(68.1)$ \\
\hline 13 & $\begin{array}{l}\text { Global cardiovascular risk assessment considers such factors as: } \square \text { Organ damage; } \\
\square \text { Metabolic disorders; } \square \text { Cardiovascular and renal disease; } \square \text { All of the above }\end{array}$ & $570(67.3)$ \\
\hline 15 & $\begin{array}{l}\text { Treatment targets for the management of diabetes type } 2 \text {, in order to reduce moderate } \\
\text { cardiovascular risk and microangiopathy, can include: } \square \mathrm{HbAlc}<7.0 \%(<53 \mathrm{mmol} / \mathrm{mol}) \text {; } \\
\square \mathrm{LDL}-\mathrm{C}<100 \mathrm{mg} / \mathrm{dL}(2.6 \mathrm{mmol} / \mathrm{L}) ; \square \mathrm{BP} \text { lowering }<130 / 80 \mathrm{mmHg} \text {; } \square \text { All of the above }\end{array}$ & $536(63.2)$ \\
\hline 3 & $\begin{array}{l}\text { Factors influencing cardiovascular risk in patients with hypertension can include: } \\
\square \text { Smoking; } \square \text { Uric acid increased levels; } \square \text { Heart rate (resting values }>80 \text { beats/min); } \\
\square \text { All of the above }\end{array}$ & $529(62.4)$ \\
\hline 4 & $\begin{array}{c}\text { Several factors can raise the risk of having hypertension, with the exclusion of: } \otimes \text { Excessive } \\
\left.\text { weight gain (BMI }>25 \mathrm{~kg} / \mathrm{m}^{2}\right) ; \square \text { Abdominal obesity; } \square \text { Waist circumference }>102 \mathrm{~cm} \text { in } \\
\text { men and }>88 \mathrm{~cm} \text { in women; } \square \text { The body mass above } 80 \mathrm{~kg}\end{array}$ & $513(60.5)$ \\
\hline 2 & $\begin{array}{l}\text { According to present European guidelines for the management of arterial hypertension, } \\
\text { hypertension (blood pressure is recorded as the average of the last two BP readings during } \\
\text { at least two repeat visits) is defined as office BP values above: } \square 140 \mathrm{mmHg} \text { (systolic blood } \\
\text { pressure-SBP) and/or } 85 \mathrm{mmHg} \text { (diastolic blood pressure-DBP); } \square 135 \mathrm{mmHg} \text { (SBP) and/or } \\
85 \mathrm{mmHg} \text { (DBP); } \square 130 \mathrm{mmHg} \text { (SBP and/or } 80 \mathrm{mmHg} \text { (DBP); } \square 140 \mathrm{mmHg} \text { (SBP) and/or } \\
\quad 90 \mathrm{mmHg} \text { (DBP) }\end{array}$ & $470(55.5)$ \\
\hline 11 & $\begin{array}{l}\text { Recommendations for pharmacological low-density lipoprotein cholesterol-lowering (statins) } \\
\text { can include: } \square \text { Patients at high (or at very high) risk of a cardiovascular event; } \square \text { Primary } \\
\text { prevention of cardiovascular events; } \square \text { Previous acute coronary syndrome; } \square \text { All of the above }\end{array}$ & $469(55.4)$ \\
\hline 7 & $\begin{array}{l}\text { The aim of treatment of arterial hypertension under the age of } 65 \text { is to reduce the increased } \\
\text { blood pressure: } \square \text { to the value of } 135 \mathrm{mmHg} \text {; } \square \text { to the value of } 130 \mathrm{mmHg} \text {; } \square \text { less than } \\
140 \mathrm{mmHg} \text {, and achieving the values }>120 \mathrm{mmHg} \text {, if well-tolerated; } \boldsymbol{\mathrm { BP }} \text { thresholds are not } \\
\text { defined if the treatment is well-tolerated }\end{array}$ & $311(36.7)$ \\
\hline 9 & $\begin{array}{l}\text { Regular physical activity may be beneficial for cardiovascular health. Hypertensive patients } \\
\text { should be advised to participate in moderate intensity dynamic aerobic exercise (walking, } \\
\text { jogging, cycling, or swimming) on at least: } \square 5-7 \text { days per week, in } 15 \text { min.; } 囚 3 \text { days per } \\
\text { week, in } 30 \text { min.; } \square 5-7 \text { days per week, in } 30 \text { min.; } \square 5-7 \text { days per week, in } 60 \text { min }\end{array}$ & $258(30.4)$ \\
\hline 14 & $\begin{array}{l}\text { Provided that the treatment is well tolerated, for people }>80 \text { years, an SBP target range is: } \\
\qquad 140-150 \mathrm{mmHg} \text {; } \ \text { under } 140 \mathrm{mmHg} ; \square \text { under } 130 \mathrm{mmHg} ; \square \text { under } 120 \mathrm{mmHg}\end{array}$ & $207(24.4)$ \\
\hline 6 & $\begin{array}{l}\text { For patients at very high risk (documented cardiovascular disease, incl. myocardial infarction } \\
\text { or stroke, or SCORE }>10 \% \text {, or diabetes mellitus with target organ damage) a therapeutic } \\
\text { regimen should achieve an LDL-C goal: } \square \text { Below } 115 \mathrm{mg} / \mathrm{dL}(3 \mathrm{mmol} / \mathrm{L}) ; \square \text { Below } \\
100 \mathrm{mg} / \mathrm{dL}(2.5 \mathrm{mmol} / \mathrm{L}) ; \text {; Below } 70 \mathrm{mg} / \mathrm{dL}(1.8 \mathrm{mmol} / \mathrm{L}) ; \square \text { Below } 55 \mathrm{mg} / \mathrm{dL}(1.4 \mathrm{mmol} / \mathrm{L})\end{array}$ & $134(15.8)$ \\
\hline 12 & $\begin{array}{l}\text { Deleterious impact on cardiovascular prognosis can have such factors as: } \square \text { Caffeine, as it } \\
\text { increases risk of hypertension in case of regular consumption; } \square \text { High-fructose corn syrup } \\
\text { due to risk of development of insulin resistance; } \square \text { Salt, and thereby salt substitutes that } \\
\text { contain potassium chloride are recommended; } \otimes \text { All of the above }\end{array}$ & $102(12.0)$ \\
\hline
\end{tabular}

$\square$ Correct answers; $\boldsymbol{\nabla}$ False answers that were given most often (At least one-third of all answers) $(\mathrm{N}=854)$ 

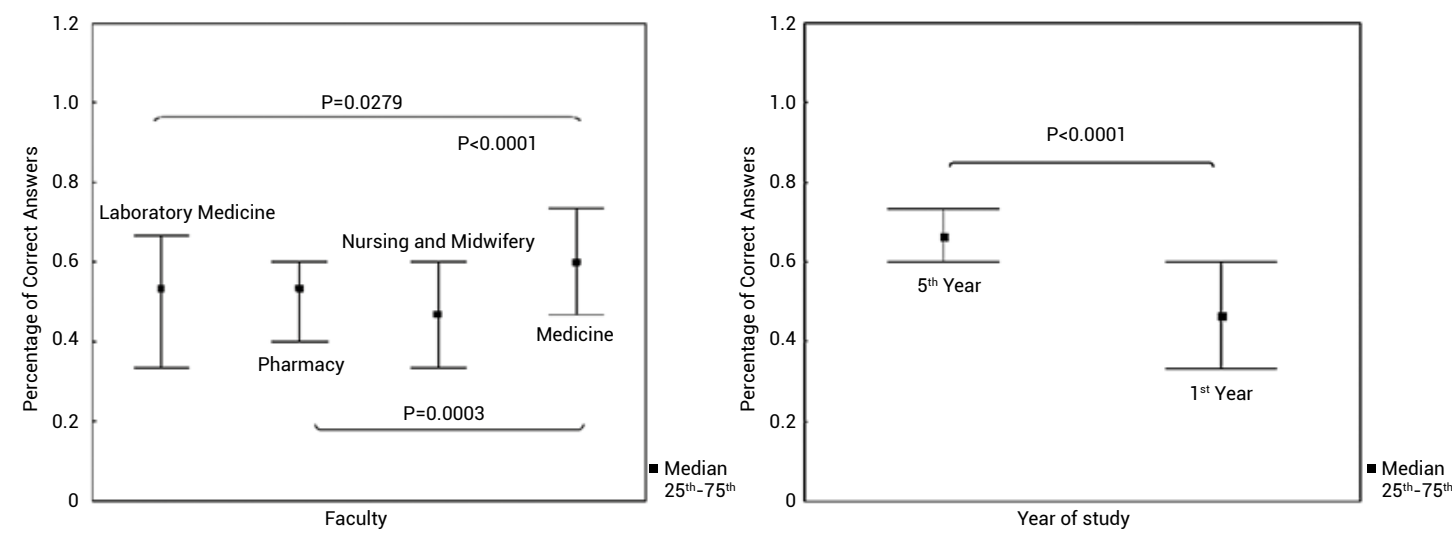

Figure 1. The results of the knowledge test. The median percentage $\left(25^{\text {th }}-75^{\text {th }}\right.$ quartile) of correct answers according to the faculty Kruskal-Wallis $(3, \mathrm{~N}=854) \mathrm{H}=46.8 ; \mathrm{P}<0.00001$ (a) and year of the study - Kruskal-Wallis $(3, \mathrm{~N}=854) \mathrm{H}=252.1 ; \mathrm{P}<0.0001$ (b).

future nurses chose hospital work $(78.7 \%$ and $96 \%$, adequately), pharmacy students indicated on community pharmacy $(57.6 \%)$, while future diagnosticians preferred Diagnostic Laboratory Centers or Blood Donation Centers. Detailed demographic characteristics and professional plans of study participants are presented in Table 2.

\section{The knowledge test}

A detailed list of questions ranged according to the percentage of correct answers is presented in Table 3. The highest percentage of correct answers was given by Medicine students: the median score was $60 \%$ with $(50-70)$ IQR $(\mathrm{P}<0.05)$. The fifth-year students were more likely to give correct answers than the first-year students $(\mathrm{P}<0.0001)$ (Figure 1).

\section{The evaluation of the 5-point Likert-like scale}

The principal component analysis revealed five factors which accounted for $65.6 \%$ of the variance:
33.3\% for 'OTHER ACTIVITIES' (5 items), 12.3\% for 'MEASUREMENTS' (4 items), $8.8 \%$ for 'EDUCATION' (4 items), 6.7\% for 'DRPs' (4 items), and $4.5 \%$ for 'INTERVIEW' (4 items). The following three out of twenty-four items were removed, as their loadings were less than 0.6: 'For better medication adherence, the pharmacist should be given the opportunity to dispense less expensive generic drug' (0.575); '(...) to monitor therapy persistence' (0.542), and 'The pharmacist should participate in optimization of pharmacotherapy for patients with cardiovascular diseases, by performing medication reviews and identification of drug-related problems and, if needed, sends to the physician (contacts the physician), in such cases as: None or incomplete drug treatment in spite of existing indication (accompanying with impaired glycemia, lipid profile or BP levels' (0.469) (Table 4 and Table 5). Finally, a modified version of the scale consisting of 21 items was created. The Cronbach's alpha was 0.861 after

Table 4. Section 3 of questionnaire. Factors identified during principal component analysis that could classify pharmacist activities.

\begin{tabular}{|c|c|c|}
\hline Question No & Factor & Item \\
\hline \multicolumn{2}{|c|}{ The pharmacist should accompany in the process of education of patients according to such cardiovascular factors as: } \\
\hline Q 1 & E1 & Smoking \\
\hline Q 2 & E2 & Lack of physical activity and/or obesity \\
\hline Q 3 & E3 & Alcohol consumption \\
\hline Q 4 & E4 & Lipid abnormalities such as hypercholesterolemia and hypertriglyceridemia \\
\hline The pharmacist should participate in some activities in order to reduce the risk of cardiovascular diseases: \\
\hline Q 5 & I1 & $\begin{array}{c}\text { Performs interview and, if needed, gives patient advice on healthy eating (incl. sodium } \\
\text { restriction and low-calorie diet) }\end{array}$ \\
\hline Q 6 & I2 & $\begin{array}{c}\text { Performs interview (incl. scoring the Fagerstrom Test for Nicotine Dependence) and, if } \\
\text { needed, gives patient advice on smoking cessation (nicotine replacement therapy, other } \\
\text { OTC medicaments) or sends to the physician }\end{array}$ \\
\hline Q 7 & I3 & Performs interview and, if needed, gives patient advice on regular exercise, or sends to the physician \\
\hline Q 8 & I4 & Performs interview and, if needed, gives patient advice on seasonal influenza vaccination \\
\hline
\end{tabular}


Table 4. Section 3 of questionnaire. Factors identified during principal component analysis that could classify pharmacist activities; cont.

\begin{tabular}{|c|c|c|}
\hline Question No & Factor & Item \\
\hline \multicolumn{3}{|c|}{ Pharmacist should participate in control of cardiovascular risk factors, and: } \\
\hline Q 9 & M1 & Measures body weight (BMI, waist circumference) and, if needed, sends to the physician \\
\hline Q 10 & M2 & Measures and initially evaluates BP levels and, if needed, sends to the physician \\
\hline Q 11 & M3 & Measures and initially evaluates glycemia and, if needed, sends to the physician \\
\hline Q 12 & M4 & $\begin{array}{l}\text { Vaccinates high-risk patients against influenza according to the physician } \\
\text { recommendations }\end{array}$ \\
\hline \multicolumn{3}{|c|}{$\begin{array}{l}\text { The pharmacist should participate in optimization of pharmacotherapy for patients with cardiovascular diseases, by } \\
\text { performing medication reviews and identification of drug-related problems and, if needed, sends to the physician } \\
\text { (contacts the physician): }\end{array}$} \\
\hline Q 13 & $\mathrm{P} 1$ & $\begin{array}{l}\text { Inappropriate duplication of therapeutic group or active ingredient }(\mathrm{Rx}, \mathrm{OTC}) \text { (eg. due } \\
\text { to self-medication, medication guided by two or more prescribers, or when patient is } \\
\text { transferred between primary, secondary and tertiary care) }\end{array}$ \\
\hline Q 14 & $\mathrm{P} 2$ & Concurrent administration of drug $(\mathrm{Rx}, \mathrm{OTC})$ and alcohol or tobacco \\
\hline Q 15 & $\mathrm{P} 3$ & $\begin{array}{l}\text { Clinically relevant drug-drug, or drug-disease interactions (eg. due to self-medication, } \\
\text { medication guided by two or more prescribers, or when patient is transferred between } \\
\text { primary, secondary and tertiary care) }\end{array}$ \\
\hline Q 16 & & $\begin{array}{l}\text { None or incomplete drug treatment in spite of existing indication (accompanying with } \\
\text { impaired glycemia, lipid profile or BP levels) }\end{array}$ \\
\hline \multicolumn{3}{|c|}{$\begin{array}{l}\text { For better medication adherence (the degree to which the patient's behavior corresponds with the agreed } \\
\text { recommendations from a health care provider), the pharmacist should be given the opportunity: }\end{array}$} \\
\hline Q 17 & A5 & To change drug formulation \\
\hline Q 18 & & To dispense less expensive generic drug \\
\hline Q 19 & P5 & $\begin{array}{l}\text { To inform patient about proper drug administration (Rx, OTC) (meal, Daytime, dividing } \\
\text { tablets/capsules) and proper storage }\end{array}$ \\
\hline Q 20 & & To monitor therapy persistence \\
\hline \multicolumn{3}{|r|}{ To perform activities listed above, the pharmacist should: } \\
\hline Q 21 & A1 & Access the information about patient (medical history, medicaments prescribed) \\
\hline Q 22 & A2 & $\begin{array}{l}\text { Access the selected patient outcomes (e.g. Ambulatory Blood Pressure Monitoring-ABPM, } \\
\text { lipid profile, glycaemia) }\end{array}$ \\
\hline Q 23 & A3 & Be given the opportunity to prescribe therapeutic agent (Rx), when justified \\
\hline Q 24 & A4 & Be given the opportunity to modify drug doses and therapeutic regimens, when justified \\
\hline
\end{tabular}

5 point Likert like scale, where $1=$ strongly disagree; $2=$ rather disagree; $3=$ undecided; $4=$ rather agree; $5=$ strongly agree. Factors: A = OTHER ACTIVITIES; E = EDUCATION; I = INTERVIEW; M = MEASUREMENT; P = DRUGRELATED PROBLEMS. The following three out of twenty four items were removed, as their loadings were less than 0.6 : Q16 (0.469); Q18 (0.575); Q20 (0.542). The Principal Component Analysis (PCA) Loadings are further presented in Appendix.

modifications of the first factor, 0.851 of the second, 0.894 of the third, 0.879 of the fourth, and 0.873 of the fifth (Table 6). The KMO value was 0.883 and can be considered a good indication that principal component or factor analysis was suitable for studying these variables. The Bartlett test (chi-square 10027.9; $\mathrm{P}<0.0001$ ) indicated absence of an identity matrix. The goodness of fit of the statistical model to the modified Likert-like scale was confirmed by confirmatory item analysis: RMSEA $<0.08(0.0733,95 \%$ CI 0.069-0.078), GFI > 0.8 (0.916).

Confirmatory item analysis revealed any positive correlation among particular factors $(>0.3)$, with the most pronounced between 'INTERVIEW' and 'EDUCATION' (0.606); 'INTERVIEW' and 'MEASUREMENTS' (0.632) or 'DRPS' and 'OTHER ACTIVITIES' (0.459).

\section{Attitude toward the role of the community pharmacist in the prevention of CVD}

Figures 2 and 3 demonstrate discrepancies in opinions, expressed as factor scores, among Medicine, Pharmacy, Laboratory Medicine, and Nursing students, as well as $1^{\text {st }}$ and $5^{\text {th }}$-year students. The significant differences among faculties were revealed for such factors as 'OTHER ACTIVITIES' 
Table 5. Principal Component Analysis (PCA) Loadings - Modified Scale.

\begin{tabular}{|c|c|c|c|c|c|c|c|}
\hline & Category & Item & $\begin{aligned} & \text { Factor } 1 \\
&- \text { Activities } \\
&\end{aligned}$ & $\begin{array}{c}\text { Factor } 2 \\
\text { - Measure- } \\
\text { ments } \\
\end{array}$ & $\begin{array}{c}\text { Factor } 3 \\
\text { - Education }\end{array}$ & $\begin{array}{c}\text { Factor } 4 \\
\text { - Dealing } \\
\text { with DRP(s) } \\
\end{array}$ & $\begin{aligned} & \text { Factor } 5 \\
&- \text { Interview } \\
&\end{aligned}$ \\
\hline E1 & \multirow{4}{*}{$\begin{array}{l}\text { Education } \\
\text { of patients } \\
\text { according } \\
\text { to CVD risk } \\
\text { factors as: }\end{array}$} & Smoking & 0.033 & 0.121 & 0.861 & 0.156 & 0.058 \\
\hline $\mathrm{E} 2$ & & $\begin{array}{c}\text { Lack of PA and/or } \\
\text { obesity }\end{array}$ & 0.032 & 0.102 & 0.892 & 0.041 & 0.127 \\
\hline E3 & & Alcohol consumption & 0.095 & 0.064 & 0.844 & 0.110 & 0.154 \\
\hline $\mathrm{E} 4$ & & High TC and TG & 0.240 & 0.103 & 0.755 & 0.156 & 0.112 \\
\hline $\mathrm{I} 1$ & \multirow{4}{*}{$\begin{array}{l}\text { Performing } \\
\text { of interview } \\
\text { giving advices } \\
\text { on: }\end{array}$} & Healthy eating & 0.092 & 0.280 & 0.477 & 0.018 & 0.618 \\
\hline $\mathrm{I} 2$ & & Smoking cessation & 0.128 & 0.360 & 0.320 & 0.243 & 0.689 \\
\hline $\mathrm{I} 3$ & & Regular exercise & 0.134 & 0.347 & 0.391 & 0.129 & 0.706 \\
\hline $\mathrm{I} 4$ & & $\begin{array}{c}\text { Seasonal influenza } \\
\text { vaccination }\end{array}$ & 0.140 & 0.251 & 0.095 & 0.283 & 0.716 \\
\hline M1 & \multirow{4}{*}{$\begin{array}{l}\text { Control of } \\
\text { CVD risk } \\
\text { factors, by }\end{array}$} & $\begin{array}{c}\text { Measurement of body } \\
\text { weight }\end{array}$ & 0.066 & 0.751 & 0.266 & -0.037 & 0.178 \\
\hline M2 & & Evaluation of BP levels & 0.161 & 0.789 & 0.095 & 0.195 & 0.186 \\
\hline M3 & & $\begin{array}{c}\text { Measurement and } \\
\text { evaluation of glycaemia }\end{array}$ & 0.141 & 0.868 & 0.125 & 0.148 & 0.074 \\
\hline M4 & & $\begin{array}{l}\text { Vaccination of high- } \\
\text { risk patients against } \\
\text { influenza }\end{array}$ & 0.079 & 0.727 & -0.015 & 0.071 & 0.157 \\
\hline $\mathrm{P} 1$ & \multirow{5}{*}{$\begin{array}{l}\text { Medication } \\
\text { reviews and } \\
\text { identification } \\
\text { of DRP: }\end{array}$} & $\begin{array}{c}\text { Inappropriate } \\
\text { duplication of } \\
\text { therapeutic group or } \\
\text { active ingredient }\end{array}$ & 0.207 & 0.177 & 0.051 & 0.851 & 0.051 \\
\hline $\mathrm{P} 2$ & & $\begin{array}{c}\text { Concurrent } \\
\text { administration of drug } \\
\text { and alcohol or tobacco }\end{array}$ & 0.105 & 0.071 & 0.137 & 0.832 & 0.197 \\
\hline P3 & & $\begin{array}{l}\text { Drug-drug or drug- } \\
\text { disease interactions }\end{array}$ & 0.280 & 0.176 & 0.129 & 0.789 & 0.092 \\
\hline $\mathrm{P} 4$ & & $\begin{array}{l}\text { None or incomplete } \\
\text { drug treatment in spite } \\
\text { of existing indication }\end{array}$ & 0.433 & 0.314 & 0.161 & 0.469 & -0.0178 \\
\hline P5 & & $\begin{array}{c}\text { Proper drug } \\
\text { administration and } \\
\text { storage }\end{array}$ & 0.346 & -0.077 & 0.125 & 0.689 & 0.094 \\
\hline A1 & \multirow{5}{*}{$\begin{array}{c}\text { Other } \\
\text { activities, } \\
\text { when justified }\end{array}$} & $\begin{array}{c}\text { Access the medical } \\
\text { information about } \\
\text { patient }\end{array}$ & 0.739 & 0.184 & 0.0803 & 0.254 & -0.048 \\
\hline A2 & & $\begin{array}{c}\text { Access the selected } \\
\text { patient outcomes } \\
\text { (ABPM, lipid profile, } \\
\text { glycaemia) }\end{array}$ & 0.728 & 0.198 & 0.083 & 0.255 & -0.118 \\
\hline A 3 & & $\begin{array}{c}\text { Prescription of } \\
\text { therapeutic agent }(\mathrm{Rx})\end{array}$ & 0.790 & -0.0822 & 0.046 & -0.011 & 0.179 \\
\hline A4 & & $\begin{array}{l}\text { Modification of drug } \\
\text { doses and therapeutic } \\
\text { regimens }\end{array}$ & 0.825 & 0.106 & -0.040 & -0.075 & 0.120 \\
\hline A5 & & $\begin{array}{c}\text { Change of drug } \\
\text { formulation }\end{array}$ & 0.792 & -0.009 & -0.008 & 0.044 & 0.078 \\
\hline & \multirow{2}{*}{$\begin{array}{l}\text { Optimization } \\
\text { of pharmaco- } \\
\text { therapy }\end{array}$} & $\begin{array}{c}\text { Dispensing less } \\
\text { expensive generic drug }\end{array}$ & 0.575 & -0.079 & 0.100 & 0.289 & 0.079 \\
\hline & & $\begin{array}{c}\text { Monitoring of therapy } \\
\text { persistence }\end{array}$ & 0.542 & 0.246 & 0.157 & 0.268 & -0.087 \\
\hline & & Variance $(\%)$ & 33.3 & 12.3 & 8.8 & 6.7 & 4.5 \\
\hline
\end{tabular}

$\mathrm{ABPM}=$ Ambulatory Blood Pressure Monitoring; $\mathrm{CVD}=$ Cardiovascular Disease; $\mathrm{DRP}=$ Drug Related Problem; $\mathrm{TC}=$ Total Cholesterol; $\mathrm{TG}=$ Triglycerides; $\mathrm{PA}=$ Physical Activity $(\mathrm{N}=248)$. 
Table 6. Item-total correlations and Cronbach's coefficient alphas resulting after confirmatory Item Analysis (CIA) and Model Re-Specification $(\mathrm{N}=248)$.

\begin{tabular}{|c|c|c|c|c|c|c|c|}
\hline \multirow[b]{2}{*}{ Factor } & \multirow[b]{2}{*}{ Item } & \multicolumn{3}{|c|}{ Primary scale } & \multicolumn{3}{|c|}{ Modified scale } \\
\hline & & $\begin{array}{l}\text { Item-total } \\
\text { correlation }\end{array}$ & $\begin{array}{l}\text { Cronbach's } \\
\text { alpha }\end{array}$ & $\begin{array}{l}\text { Cronbach's alpha } \\
\text { if item deleted }\end{array}$ & $\begin{array}{l}\text { Item-total } \\
\text { correlation }\end{array}$ & $\begin{array}{l}\text { Cronbach's } \\
\text { alpha }\end{array}$ & $\begin{array}{l}\text { Cronbach's alpha if } \\
\text { item deleted }\end{array}$ \\
\hline \multirow{5}{*}{$\begin{array}{c}\text { Factor } 1 \\
- \text { Activities }\end{array}$} & A1 & 0.719 & \multirow{5}{*}{0.845} & 0.788 & 0.695 & \multirow{5}{*}{0.861} & 0.828 \\
\hline & A2 & 0.708 & & 0.792 & 0.684 & & 0.831 \\
\hline & $\mathrm{A} 3$ & 0.639 & & 0.822 & 0.672 & & 0.834 \\
\hline & A4 & 0.662 & & 0.812 & 0.718 & & 0.822 \\
\hline & A5 & - & & - & 0.627 & & 0.845 \\
\hline \multirow{4}{*}{$\begin{array}{c}\text { Factor } 2- \\
\text { Measurements }\end{array}$} & M1 & 0.650 & \multirow{4}{*}{0.851} & 0.828 & 0.650 & \multirow{4}{*}{0.851} & 0.828 \\
\hline & M2 & 0.759 & & 0.785 & 0.759 & & 0.785 \\
\hline & M3 & 0.796 & & 0.765 & 0.796 & & 0.765 \\
\hline & M4 & 0.579 & & 0.861 & 0.579 & & 0.861 \\
\hline \multirow{4}{*}{$\begin{aligned} & \text { Factor } 3 \\
&- \text { Education }\end{aligned}$} & E1 & 0.804 & \multirow{4}{*}{0.894} & 0.853 & 0.804 & \multirow{4}{*}{0.894} & 0.853 \\
\hline & E2 & 0.812 & & 0.849 & 0.812 & & 0.849 \\
\hline & E3 & 0.779 & & 0.859 & 0.779 & & 0.859 \\
\hline & $\mathrm{E} 4$ & 0.689 & & 0.891 & 0.689 & & 0.891 \\
\hline \multirow{5}{*}{$\begin{array}{c}\text { Factor } 4- \\
\text { Dealing with } \\
\text { DRP(s) }\end{array}$} & $\mathrm{P} 1$ & 0.783 & 0.855 & 0.780 & 0.822 & 0.879 & 0.810 \\
\hline & $\mathrm{P} 2$ & 0.693 & & 0.820 & 0.761 & & 0.835 \\
\hline & P3 & 0.815 & & 0.769 & 0.770 & & 0.832 \\
\hline & $\mathrm{P} 4$ & 0.543 & & 0.891 & - & & - \\
\hline & $\mathrm{P} 5$ & - & & - & 0.606 & & 0.891 \\
\hline \multirow{4}{*}{$\begin{array}{l}\text { Factor } 5 \\
- \text { Interview }\end{array}$} & I1 & 0.694 & \multirow{4}{*}{0.873} & 0.853 & 0.694 & \multirow{4}{*}{0.873} & 0.853 \\
\hline & $\mathrm{I} 2$ & 0.798 & & 0.811 & 0.798 & & 0.811 \\
\hline & $\mathrm{I} 3$ & 0.842 & & 0.792 & 0.842 & & 0.792 \\
\hline & I4 & 0.595 & & 0.888 & 0.595 & & 0.888 \\
\hline
\end{tabular}

\# $\mathrm{P}<0.0001$

(factor 1; P $<0.0001$ ), 'EDUCATION'(factor 3; $\mathrm{P}=0.0109$ ), 'DRPs' (factor 4 ; $\mathrm{P}<0.0001$ ). The particular items that made up these factors were more approved by pharmacy students (Figure 2).

Fifth year students tended to be more positive than first years in relation to factor $3(\mathrm{P}=0.0022)$ and factor $4(\mathrm{P}=0.0002)$ and more negative in relation to factor $1(\mathrm{P}=0.0013)$.

Regarding the options rather agree and strongly agree, the top activities, that were approved most, concerning information given to patients about proper drug administration and storage (factor P5) with the responses ranging from 77.0 to $93.6 \%$ according to the faculty; education about such risk factors as smoking (E1) ranged from $71.0-87.7 \%$; high lipid levels (E4) ranged from $72.6-86.8 \%$ of responses; identification of DRPs related to concurrent administration of drug and alcohol or tobacco (P2) ranged from 74.2-87.2\% of responses. Managing with DRPs related to drug-drug interactions (P3) was also highlighted by future medicine doctors, diagnosticians, and especially pharmacists (72.5-83.9\% of responses) and less by future nurses and midwives (69.6\%).

For all the items that were classified to the category 'DRPs', significant differences were denoted between the last two subgroups of students $(\mathrm{P}<0.05)$. The less preferable were prescription of therapeutic agent, when justified (A3), modification of drug doses and therapeutic regimens (A4), or change of drug formulation (A5). In this case, the responses: rather disagree and strongly disagree were given by $25.1-45.2 \%$ of Laboratory Medicine, Medicine or Nursing students. Also, every fifth student was against the pharmacists' access to patient medical documentation (A1) and clinical/laboratory findings (ABPM, lipid profile, glycemia) (A2). However, a higher percentage of future pharmacists $(\mathrm{P}<0.00001)$ than students of other faculties considered all mentioned (A1-A5) items as important activities for CVD risk prevention. There were no discrepancies among faculties as regards attitude toward such particular items as measurements 

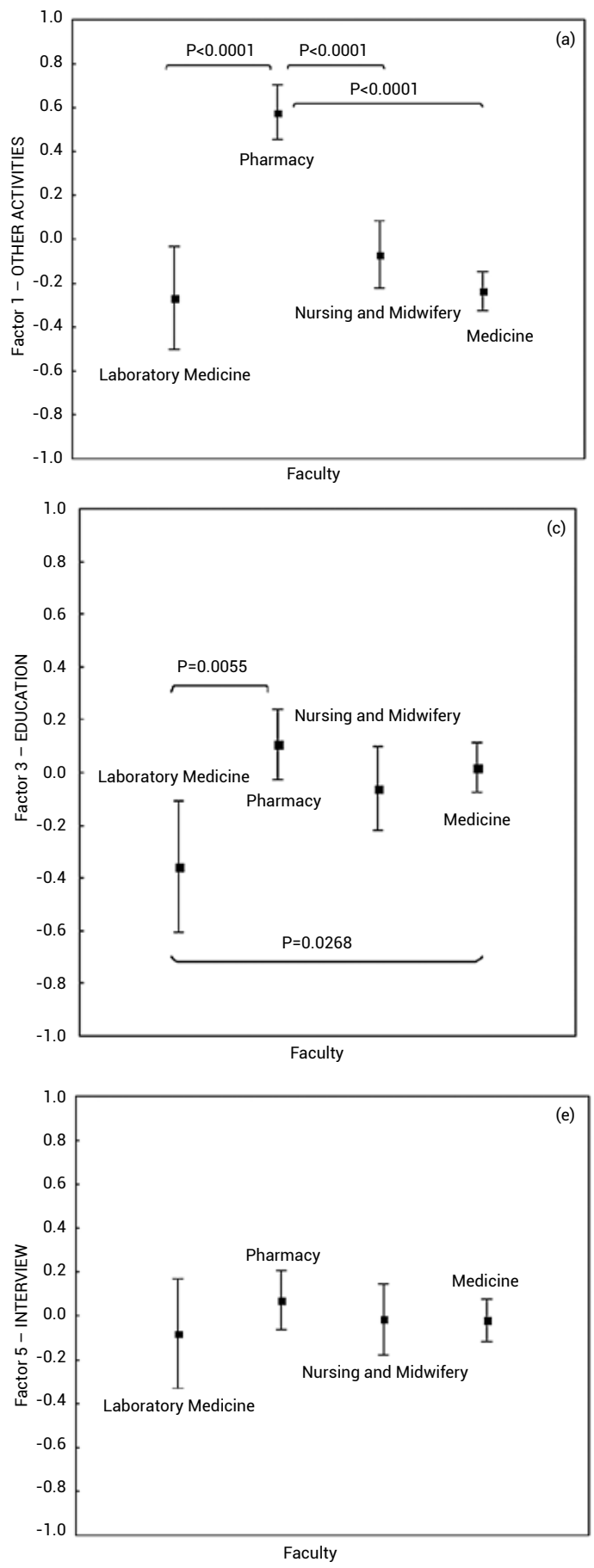

(BP, glycemia) and vaccinations (M1-M4) as well as performing interview (I1-I4). Similarly, no significant differences were found for factors that were attributed to the above items in factor analysis.

No significant positive correlations $(\mathrm{P}<0.05)$ were found between the summarized score for the knowledge test and loading factors, i.e. factor 1 (OTHER ACTIVITIES), factor 3 (EDUCATION), and factor 4 (DRPs).
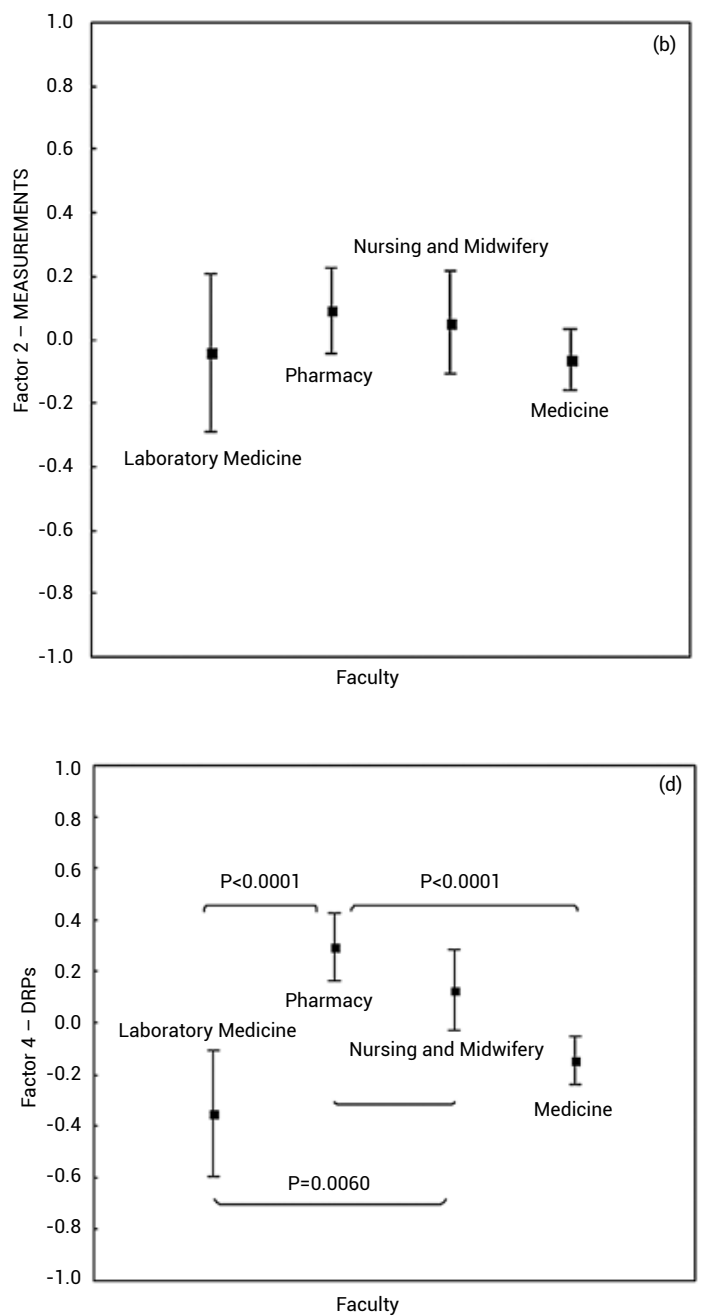

Figure 2. Attitudes toward community pharmacists' contribution in prevention of cardiovascular diseases according to the faculty - with increased factor loadings (Principal component analysis - PCA) the opinions were more positive - Kruskal-Wallis $(3, \mathrm{~N}=847)$,

(a) Factor 1: $\mathrm{H}=107.57 ; \mathrm{P}<0.0001$,

(b) Factor 2 : $\mathrm{H}=6.29 ; \mathrm{P}=0.10$,

(c) Factor $3: \mathrm{H}=11.16 ; \mathrm{P}=0.0109$,

(d) Factor 4: $\mathrm{H}=44.29 ; \mathrm{P}<0.0001$,

(e) Factor 5: $\mathrm{H}=0.97 ; \mathrm{P}=0.81$.

The willingness to take common classes with other faculties of Medical University was expressed significantly more by future pharmacists $(\mathrm{P}<0.0001)$ as compared to other respondents. The percentage of positive answers (agree or strongly agree) exceeded $75 \%$ for pharmacy students, $55 \%-$ medicine students, $50 \%$ - future nurses, and only $40 \%$ - diagnosticians. There were no discrepancies in such expectations according to the study year 

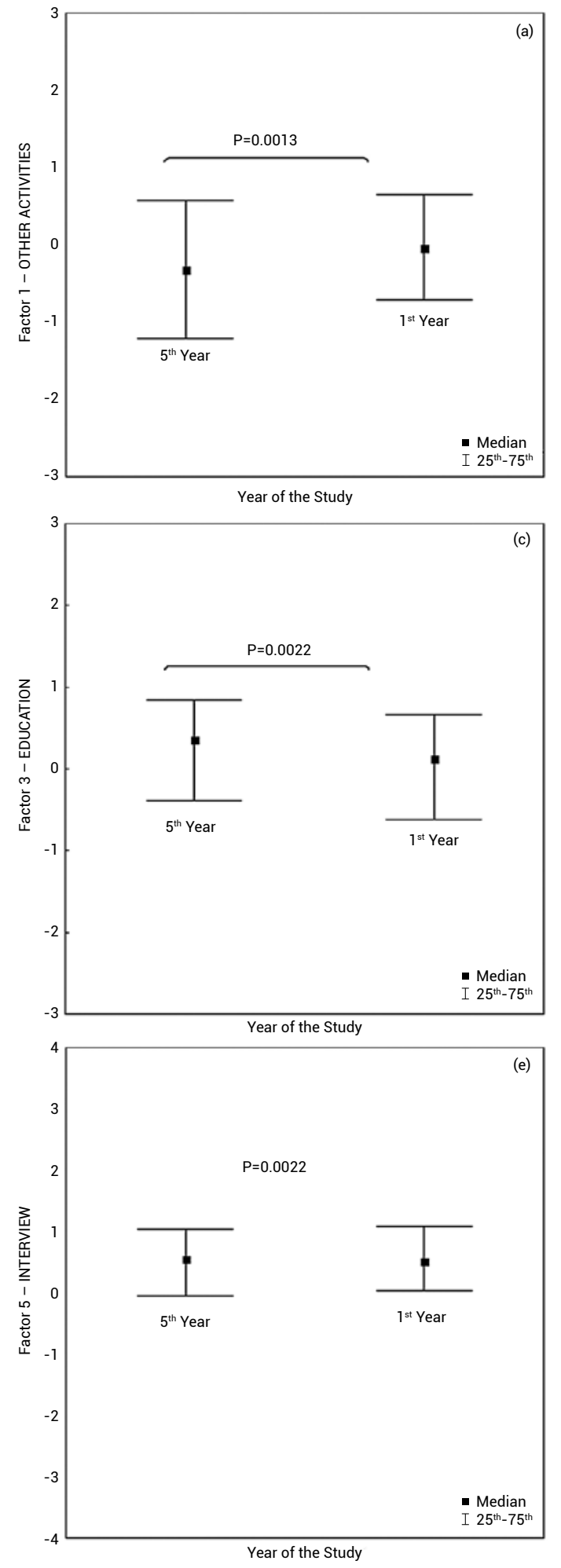

(Figure 4). The students who gave their positive opinion about such community pharmacists competencies as access to medical/diagnostic data about a patient, modification of drug doses, or formulation (A1-A5) were more interested in inter-faculty
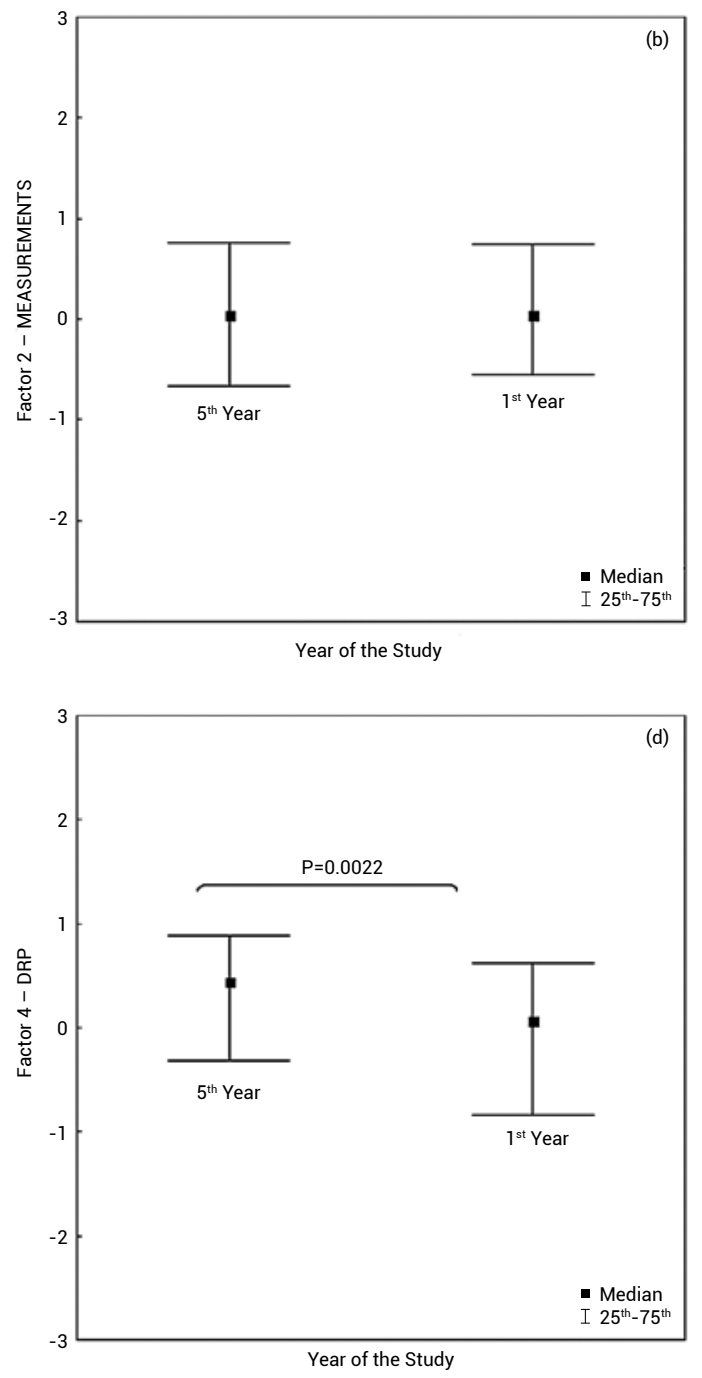

Figure 3. Attitudes toward community pharmacists' contribution in prevention of cardiovascular diseases according to the year of the study - with increased factor loadings (Principal component analysis - PCA) the opinions were more positive U Mann-Whithey ( $\mathrm{N}=847)$,
(a) Factor 1: $\mathrm{P}=0.0013$,
(b) Factor 2: $\mathrm{P}=0.3742$,
(c) Factor 3: $\mathrm{P}=0.0022$,
(d) Factor 4: $\mathrm{P}=0.00024$
(e) Factor 5: $\mathrm{P}=0.1897$.

courses on selected issues of pharmacotherapy; $\mathrm{R}($ Spearman) $>0.3, \mathrm{P}<0.05$.

Demographic characteristics of respondents incl. place of residence did not determine their opinions about the role of the pharmacist. 

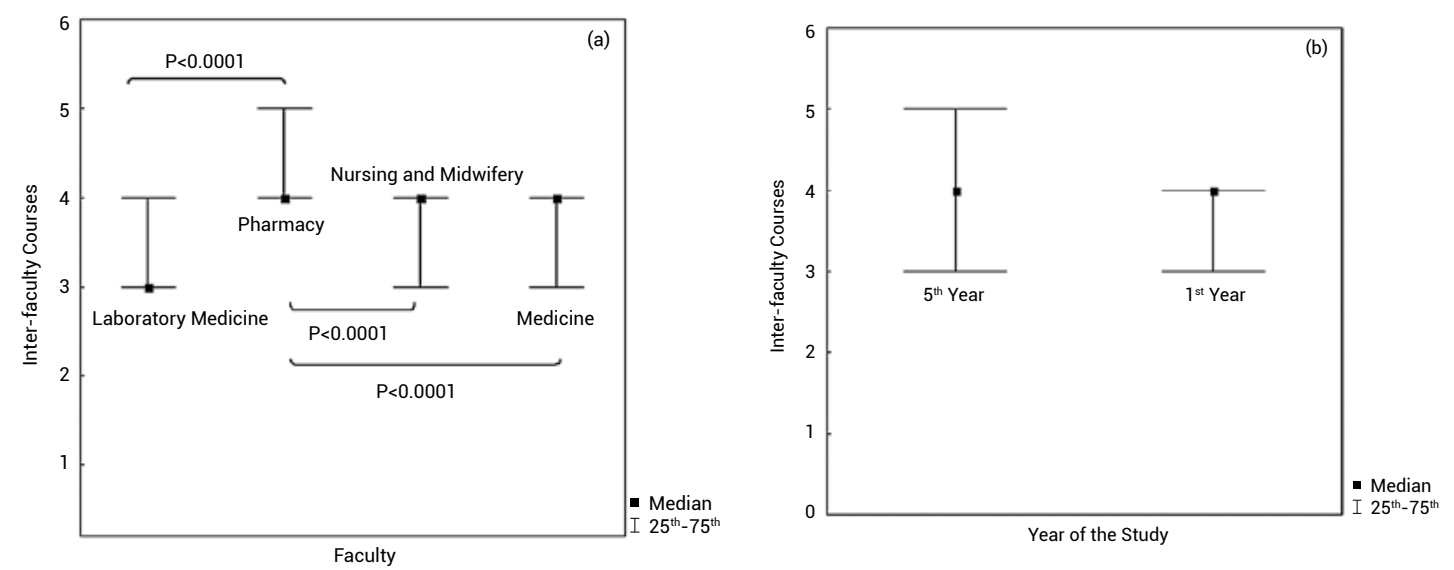

Figure 4. The willingness to take part in inter-faculty courses. The results are demonstrates as median of responses according to five-point Likert scale - Kruskal-Wallis $(\mathrm{N}=847)$, according to the faculty $-\mathrm{H}=44.9 ; \mathrm{P}<0.0001$ (a) and year of the study $-\mathrm{H}=2.5 ; \mathrm{P}=0.1146$ (b).

\section{DISCUSSION AND CONCLUSION}

The activities of community pharmacists in relation to their patients with CVD risk or disease focus on patient education and counseling as well as optimization of pharmacotherapy. There is hence a constant need for updating interdisciplinary knowledge according to current international guidelines. In the present study, older students of all the faculties had better knowledge about risk factors for CVD than younger students who had not had lessons in epidemiology or pharmacotherapy. A surprisingly low number of students (less than 40 percent) were familiar with actual recommended BP levels according to patient age or LDL-C goals for hypolipidemic therapy. Also, the awareness about dealing with modified CVD risk factors (diet, physical activity) seemed to be insufficient. Similar results were obtained by other authors, who found student knowledge of international guidelines to be unsatisfactory (13). However, more than $90 \%$ of students were familiar with the problem of smoking and recommended tools for smoking cessation.

Next in the current survey, the participants were asked to refer to several proposals of community pharmacists activity when managing CVD patients. According to the common definition of pharmaceutical care (3), the pharmacist is expected to work in concert with the patient's other healthcare providers; hence the current survey was introduced not only to the future physicians but also to nurses and diagnosticians. Validation of the self-administered questionnaire based on a Likert-like scale displayed acceptable construct validity and internal consistency. The questionnaire comprised five factors that could describe such activity, all of which demonstrated good internal consistency. Particularly, the top activities that were indicated by respondents included information given to patients about proper drug administration and storage, education about such risk factors as smoking and high lipid levels, or identification of DRPs related to concurrent administration of drug and alcohol or tobacco. These items were awarded the highest approval, independently of study faculty, and seem to be well-known from the ordinary practice of community pharmacists. In general, any significant discrepancies among students were not provoked by items that could be classified to categories: 'INTERVIEW' (and giving advice according to lifestyle modifications) or 'MEASUREMENTS' (BP, glycemia, lipids). The examples of proposed actions included in the survey have been included in novel polish law regulations concerning the profession of pharmacist; e.g. evaluations of BP, glycemia, lipid parameters, or vaccinations against influenza. The final item has been the subject of much debate, but without clear recommendations. The question of the contribution of the community pharmacist into immunization may arise with the development of a vaccine against SARS-CoV-2. Significant differences were found among respondents with regard to dealing with drug-related problems and widely understood optimization of pharmacotherapy. In Poland, like in most industrialized countries, the population has been aging; this has led to an increased health care burden coupled with the use of many medications (Rx, OTC) by patients. Medication reviews have been proposed as a useful tool in order to manage this situation. For several years, during their curriculum, Pharmacy students have been taking part in classes where they can acquire skills according to the identification of DRPs (14). So it is not surprising that such service has achieved a great acceptance of this subgroup of respondents. Managing with DRPs 
related to drug-food, or drug-drug interactions was also approved by future medicine doctors and diagnosticians, and less by future nurses and midwives. The category that strongly divided the respondents was access to the information about patient medical history and prescribed medications, patient outcomes as well as the opportunity to prescribe $\mathrm{Rx}$ medication, modification of dosage schedule or drug formulation ('OTHER ACTIVITIES'). Again, the pharmacy students presented a more positive attitude to the proposed services. Current pharmaceutical care models - also these considered in novel Polish regulations - suggest that pharmacists could perform medication reviews in order to evaluate the drug-related problems, and then develop patient care plans and monitoring. Such a service would make drug therapy more effective and safe for individual patients but it requires a strong communication link between the physician and the pharmacist, as well as more detailed knowledge about patient history than could be obtained during a conversation with the patient. Community-based information systems would facilitate the exchange of information between pharmacists and other members of the health care team. In Poland, from January 2020 physicians are obliged to prescribe the medicines to the patient using electronic prescriptions. The E-prescription is saved on the Patient's Internet Account, and the electronic record is transferred via a system from a doctor to a pharmacist, and from there to the institution that reimburses a given drug. Access to more detailed data about the patient, than only a single record containing the current prescription, is theoretically possible but no further action has yet been taken by the Polish authorities.

A patient-centered approach requires the pharmacist to work in collaboration with other health care providers. This would enable the pharmacist to monitor, initiate, and modify medication use as well as to prevent or identify and solve drug-related problems during medication reviews. Some authors report fewer barriers and fewer difficulties in contact with general practitioners when the pharmacists were employed in rural and provincial regions. In this case, the long-lasting relationships with local physicians were mostly characterized by mutual trust and appreciation (15). However, in the current survey, the attitudes toward the role of community pharmacists did not differ when considering students from urban and rural areas, separately.

Such interprofessional collaboration between pharmacists and other health care providers, especially with physicians, would enhance the advisory role of the pharmacist. Participation in interfaculty meetings and direct relationships among health care providers would create favorable conditions for such collaboration through the interchange of opinions and information and could convince about mutual competencies (15). For better results, this process should start at the university level from interprofessional education (16).

Our results suggest that student expectations of the pharmacist's role did not evolve much over the course. The $5^{\text {th }}$ year student opinions have become more positive in only two out of five factors that could define several activities in community pharmacy ('EDUCATION' and 'DRPs'). It can be suggested that the attitudes of particular groups of future health care providers, due to lack of adequate courses, are influenced mainly by common society opinions. The student gaining knowledge about cardiovascular risk also had a moderate impact on his choices. The respondents who have achieved a better score in the test tended to demonstrate greater approval of the role of the pharmacist in patient education or dealing with DRPs, as well as access to medical data about the patient and the opportunity to change drug formulation or dosage schedules.

However, the willingness to take common classes with other faculties was expressed significantly more by future pharmacists (more than $70 \%$ of answers being agree or strongly agree). It can be hypothesized that a lack of interest in interfaculty courses would result in a future lack of cooperation after graduating. Interestingly, the students who were more interested in inter-faculty courses gave a positive opinion about such community pharmacist competencies as access to medical/diagnostic data about the patient, modification of drug doses, or formulation. Similar results were obtained by Piecuch et al. (2014) (16). The concept of pharmaceutical care was more prevalent for medical students who reported having more frequent relationships with pharmacy students, students who reported having scientific relationships, and students who participated in community services together with pharmacy students. More than seventy percent of medical students claimed that they do not consider themselves prepared for future collaboration with pharmacists.

Another point is that while future diagnosticians, nurses, and medicine doctors were constant in their choices of the future professional carrier, some discrepancies can be noticed in the case of future pharmacists. In our previous work, a similar trend was observed with $5^{\text {th }}$-year students favoring pharmacy work and $1^{\text {st }}$-year students - the pharmaceutical industry. The conclusion was that after the 
5-year course, students are not convinced about the opportunity to achieve job development in the areas outside that of the community pharmacy. This in turn might emphasize the constant need to focus on more practical specialized knowledge and skills through the Curriculum, which also considers the variety of modern applications available in pharmaceutical science (17).

The question about a patient with CVD risk/ disease has become the starting point to a more universal discussion on community pharmacists' competencies in the area of pharmaceutical care. Our results indicate that future medicine doctors, diagnosticians, and nurses have an unclear picture of pharmacists as a health care profession. There are numerous reasons for that, including novel law regulations as well as a gap in the teaching of future health care provides. From the pharmacists' view, there can be a lack of time or insufficient communication skills, as well as a requirement for actual knowledge about advanced pharmacology, pharmacotherapy, and drug interactions (18). It also cannot be excluded that some community pharmacists avoid interprofessional contact and delegate responsibility for patient safety to the patient himself (19). In the present survey, we focus only on the single aspectmedical education, changes of which should be accompanied by up-to-date law regulations. It can be suggested that such Curriculum updates would enable future collaboration of health care providers with community pharmacists who could go beyond dispensing of medicines and giving information related to proper usage and storage after the legal provisions extending pharmacist's rights come into force. In details,

- The validated self-administered questionnaire comprising five factors displayed acceptable construct validity and internal consistency and therefore can be proposed as an example tool to assess the particular activities of community pharmacists in the pharmaceutical area.

- There is a need to design effective interprofessional workshops and activities aimed at increasing future health care providers' awareness of areas where a pharmacist can, or should, be more engaged.

- The interfaculty classes could be the starting point for collaboration among members of particular medical professions, in the future.

\section{Limitations of the study}

The sample of size $(\mathrm{N}=847)$ was sufficient for the validation of the Likert-like scale -35.3 cases per item ( 40.3 cases per item - after deletion of
3 items). Secondly, while our findings refer to the Polish pharmaceutical market, they closely resemble the findings of other researchers who indicate difficulties and barriers to strengthen pharmaceutical service in their countries. In this context, the obtained results may be universal. Another limitation is that due to lack of data the comparison of demographic characteristics of respondents and nonrespondents was not performed. A 5-point Likert Scale was used rather than a 7-point scale, as it was reported to be less confusing, readily comprehensible to respondents and better enabled them to express their views. Another limitation concerns the limited number of questions included in part two of the questionnaire. The present survey did not aim to test student knowledge in the area of cardiovascular risk and diseases in detail but rather the obtained result was to be another factor to correlate with the evaluated attitudes toward proposed community pharmacist activities. Finally, as the respondents were students at Medical University, their opinions may not reflect those of their older colleagues, but the study concerned aspects of medical education that in some way impacts the future attitudes of professional health care providers.

\section{Conflict of interest}

The authors report no conflicts of interest.

\section{REFERENCES}

1. https:/ec.europa.eu/eurostat/statistics-explained/ pdfscache/37359.pdf (accessed on 15.05.2020).

2. Zolezzi M., Abdallah O., Kheir N., Abdelsalam A.G.: Res. Social. Adm. Pharm. 15, 252 (2019).

3. Hepler C.D., Strand L.M.: Am. J. Hosp. Pharm. 47, 533 (1990).

4. https://isap.sejm.gov.pl/isap.nsf/DocDetails. $\mathrm{xsp}$ ?id=WDU20210000097 (accessed on 16.01.2021).

5. https://www.pgeu.eu/wp-content/uploads/ 2019/04/PGEU-AR-2017-WEB.pdf (accessed on 15.05.2020).

6. Bach A.T., Goad J.A.: Integr. Pharm. Res. Pract. 4, 67 (2015).

7. Yuan C., Ding Y., Zhou K., Huang Y., Xi X.: Health Soc. Care Community 27, e567 (2019).

8. Song Y., Barthold D.: Health Econ. 27, 1717 (2018).

9. Sousa Pinto G., Bader L., Billberg K., Criddle D., Duggan C., et al.: Res. Social Adm. Pharm. 16, 974 (2020). 
10. Sng Y., Ong C.K., Lai Y.F.: Eur. J. Hosp. Pharm. 26, 157 (2019).

11. Blondal A.B., Jonsson J.S., Sporrong S.K., Almarsdottir A.B.: Int. J. Clin. Pharm. 39, 945 (2017).

12. Swieczkowski D., Merks P., Jaguszewski M., Siluk D.: Acta Pol Pharm 74, 1021 (2017).

13. Maksimović M.Ž., Marinković J.M., Vlajinac H.D., Maksimović J.M., Tomanić M.S., et al.: Wien. Klin. Wochenschr. 129, 458 (2017).

14. Adams A.J., Weaver K.K.: Ann. Pharmacother. 50, 778 (2016).

15. Löffler C., Koudmani C., Böhmer F., Paschka S.D., Höck J., et al.: BMC Health Serv. Res. 17, 7 pages (2017).
16. Piecuch A., Pawłowicz P., KozłowskaWojciechowska M., Waniewski S., MakarewiczWujec M.: J. Interprof. Care 28, 579 (2014).

17. Jasinska-Stroschein M., Kurczewska U., Orszulak-Michalak D.: Acta Pol. Pharm. 74, 1001 (2017).

18. Barr H., Freeth D., Hammick M., Koppel I., Reeves S.: J. Interprof. Care 20, 75 (2006).

19. Puspitasari H.P., Aslani P., Krass I.: Int. J. Clin. Pharm. 37, 834 (2015). 